\title{
Editorial: Welcome to the Film Education Journal
}

\author{
Jamie Chambers* - University of Edinburgh, UK \\ Mark Reid - British Film Institute, UK \\ Andrew Burn - UCL Institute of Education, UK
}

Film is a distinct medium with a distinct history and, as such, requires a distinct pedagogy. Given the growing conversations about film education internationally, in parallel with increasingly transnational screen cultures and the corresponding evolutions in film education practice, it is high time for a publication that specifically concerns itself with distinct pedagogical approaches to film.

Considering the still-peripheral status of film in diverse curricula worldwide, it is also imperative that film educators find ways of speaking to each other, and pursue opportunities to make connections, collaborations and alliances with the work of film educators elsewhere in the world. It is important to illuminate that which is obscured, to make connections and comparisons between disparate, divergent practices, and to strengthen and elaborate pre-existing connections between localized instances in order to begin elucidating a global perspective upon film education so that the widespread marginality of film can be countered. This is what the Film Education Journal sets out to do.

Considering now our inaugural issue, we remain struck by the sense of possibility inherent within the notion of a global film education journal; by the scale of possibilities that might be opened up by an ongoing, international forum for discussion about film education. As editors, we are conscious of being custodians of something valuable. This is particularly so when one considers the frequent lack of distinction between those writing and thinking about film education and those directly involved in film education. The Film Education Journal thus attempts to harness the stimulating possibility of not only commenting and contributing, but also actively participating in and shaping the international conversation about what film education was, is and could be, through a sense of activism.

Despite the need for a distinct pedagogy, film education is interdisciplinary by nature and requires intersecting perspectives: a single field, yes, but one that requires the intersecting perspectives, experience and expertise of film-makers, classroom teachers, policymakers, youth and council workers, technicians, education officers in cultural institutions and - of course - students. A fertile discourse on film education must therefore be omnivorous, drawing from different languages, vocabularies, epistemologies and locations; from film culture, film practice, film theory, alongside educational practice and educational theory, and - crucially - from the specific experiences of practitioners and teachers on the ground. This sense of the interdisciplinary, and the productive tension between different registers and experiences of film education, is one we are firmly committed to exploring in the ongoing life of the journal, in attempting to create a platform that is as accessible to practitioners working in classrooms as it is to scholars working within the academy.

While the primary intention of the Film Education Journal is to foster and further an international discourse upon diverse film education practices, this is not a conversation we claim to inaugurate, and we hereby acknowledge a debt of gratitude 
to the pre-existing forums in which we were invited to join international, intercultural conversations about film education, key among them 'Le cinéma, cent ans de jeunesse' of the Cinémathèque française, which each year brings together film education practitioners from all over the world to commune, commingle and collaborate in Paris.

Our own experience and understanding of film education has been considerably stimulated and emboldened by opportunities to learn from practices and approaches taking place elsewhere. The work of Alain Bergala in France initially brought us, the three editors, together. Seeking somewhere to publish our discussions on 'Le cinéma, cent ans de jeunesse' project (for which Bergala serves as an artistic lead), we realized there was not any publication dedicated to the specific questions surrounding film education. Therefore, we set out to create one.

Our inaugural issue is explicitly set out as a point of departure: each editor has contributed an essay, and contributions from two members of our editorial committee, Alejandro Bachmann and Bettina Henzler, also appear. In doing so we hope to provide a clear presentation of the editorial and discursive starting point for the Film Education Journal.

Our first issue revolves around a specific theme, exploring the significance of Alain Bergala's The Cinema Hypothesis, one of the early canonic texts for a global field of film education and a body of ideas that has exerted considerable influence upon many members of our editorial team. Publication in English of The Cinema Hypothesis, 14 years after it was published in French (Bergala, 2002, 2016), invites us to reconsider its significance and influence within a developing international landscape of film education, and provides the opportunity to revisit Bergala's ideas from a number of diverse perspectives.

The journal establishes a European context and sociocultural framework in which to situate The Cinema Hypothesis, through Mark Reid's reflection upon the findings of the Screening Literacy survey led by the British Film Institute, broad trends in film education provision across Europe, and Bettina Henzler's longitudinal, historical comparison between the respective national film education cultures in France and Germany. Both articles serve to situate Bergala's ideas within a wider European context, both historically and geographically. Henzler's article is also the first in a series of significant pieces published elsewhere that the journal will be publishing in English for the first time.

Continuing in a topographic vein, yet countering the European framing of the previous articles, Jamie Chambers revisits The Cinema Hypothesis within emergent global perspectives upon film education, exploring the continued suitability of Bergala's work as an agent of interconnection that gestures towards the universal. Andrew Burn also makes direct address to The Cinema Hypothesis, challenging Bergala's dismissal of semiotics and measuring the author's theory of ciné-pedagogy before a multimodal critique.

Following these more theoretical considerations of The Cinema Hypothesis, Scottish primary school teachers Aoife Donnelly and Avril Whelan present a detailed case study of the Bergala-inspired 'Le cinéma, cent ans de jeunesse' programme in action in the classroom, and the resulting film See You Tomorrow, which is itself available to watch (CCAJ, 2017). Also employing the format of a case study, Alejandro Bachmann and Manuel Zahn use their specific experiences of film education at the Austrian Film Museum and the KurzFilmSchule respectively to explore broader reflections upon the mediating role of institutions within programmes of film education and a theory of 'media ecology'. 
Finally, we conclude with two studies using The Cinema Hypothesis as a point of departure to explore the concept of film education in relatively unexplored new directions. Alexis Gibbs provides a lively counter to Bergala in exploring the possibility of removing the teacher, or passeur, from film education altogether in order to let cinema function as an education on its own terms, while Cary Bazalgette challenges the emphasis in The Cinema Hypothesis on film education in primary schools by exploring the manner in which 2-year-olds experience cinema.

In conclusion, in instituting a forum that aspires to encompass global perspectives upon film education - a publication aiming to channel, cultivate and consolidate the many diverse voices involved in film education worldwide - we are aware of the considerable responsibility facing us as editors. We are conscious, in particular, that the Film Education Journal is an English-language publication, edited by three white men, arising from the United Kingdom. While we make no apology for the enthusiasm, ideas and commitment that led us to conceive of and institute this initiative, we remain keenly aware that the Film Education Journal must remain open to what Bergala has referred to as altérité (otherness), and what Ella Shohat and Robert Stam (1994: 48) have described as 'polycentric multiculturalism'. Considering our first issue, we are particularly aware of the underlying Eurocentrism articulated by our inaugural roster of contributions, an emphasis we intend to counter with our next themed issue of FEJ: 'Film education outside the West' (deadline for submissions: 21 February 2019).

In attempting to honour the possibility of the utopian, the Film Education Journal will endeavour to create a discursive space that remains permeable to difference and disruption, inviting a healthy diversity of voices and perspectives, prioritizing not a harmonious sense of consensus and cohesion, but rather a comradely sense of dialectic. For that conversation to flourish, we need diverse voices and perspectives. We hope you will consider joining us and adding your own voice as the discussion begins.

\section{References}

Bergala, A. (2002) L'hypothèse cinéma: Petit traité de transmission du cinéma à l'école et ailleurs. Paris: Cahiers du cinéma.

Bergala, A. (2016) The Cinema Hypothesis: Teaching cinema in the classroom and beyond (FilmmuseumSynemaPublikationen 28). Trans. Whittle, M. Vienna: Austrian Film Museum.

CCAJ (Le cinéma, cent ans de jeunesse) (2017) ECOSSE - See You Tomorrow [Video]. Online. https://vimeo.com/221750662 (accessed 22 February 2018).

Shohat, E. and Stam, R. (1994) Unthinking Eurocentrism: Multiculturalism and the media (Sightlines). London: Routledge.
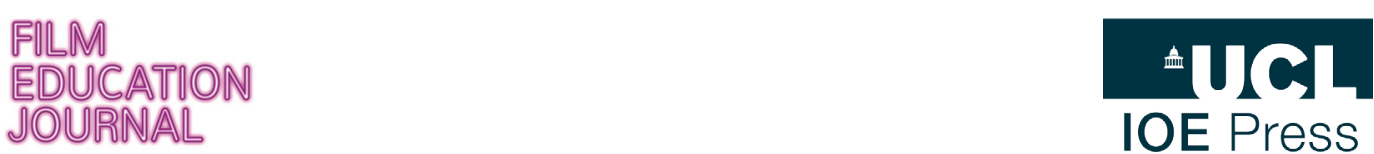

The papers in this special first issue of the Film Education Journal explore the significance of Alain Bergala's The Cinema Hypothesis. They are:

Bachmann, A. and Zahn, M. (2018) 'Film education as a multiplicity of practices: A media-ecological perspective'. Film Education Journal, 1 (1), 78-89.

Bazalgette, C. (2018) 'Researching prior learning: How toddlers study movies'. Film Education Journal, 1 (1), 101-112. 
Burn, A. (2018) 'Reflections on The Cinema Hypothesis: A response to Alain Bergala'. Film Education Journal, 1 (1), 51-63.

Chambers, J. (2018) 'Towards an open cinema: Revisiting Alain Bergala's The Cinema Hypothesis within a global field of film education'. Film Education Journal, 1 (1), 35-50.

Donnelly, A., Whelan, A. and Chambers, J. (2018) 'See You Tomorrow: A case study of the Understanding Cinema project at Granton Primary School in Edinburgh'. Film Education Journal, 1 (1), 64-77.

Gibbs, A. (2018) 'Film education otherwise: A response to Bergala's dialectics of cinema and schooling' Film Education Journal, 1 (1), 90-100.

Henzler, B. (2018) 'Education à l'image and Medienkompetenz: On the discourses and practices of film education in France and Germany'. Film Education Journal, 1 (1), 16-34.

Reid, M. (2018) 'Film education in Europe: National cultures or European identity?' Film Education Journal, 1 (1), 5-15. 